\title{
The effect of season and melatonin on GnRH-induced LH secretion in oestradiol-treated orchidectomized sheep
}

\author{
H Sakurai and T E Adams \\ Department of Animal Science, University of California, Davis, California 95616, USA \\ (Requests for offprints should be addressed to T E Adams)
}

\begin{abstract}
The biphasic effect of oestradiol $\left(\mathrm{E}_{2}\right)$ on gonadotrope responsiveness is clearly evident in orchidectomized sheep (wethers) receiving $\mathrm{E}_{2}$ and hourly pulses of GnRH. We hypothesized that the duration of $\mathrm{E}_{2}$-induced reduction in gonadotrope responsiveness differed between the breeding (November) and anoestrous (May) seasons in sheep. To test this hypothesis wethers ( $n=6 /$ group) were infused (i.v.) with $\mathrm{E}_{2}(2 \mu \mathrm{g} / 50 \mathrm{~kg}$ per $\mathrm{h})$ and received hourly pulses of $\mathrm{GnRH}$ (200 ng/50 kg per pulse) or saline in May or November. The pattern of LH secretion during the $72 \mathrm{~h}$ infusion period was determined. Serum concentrations of LH did not differ with season in control wethers receiving vehicle alone. Similarly, continuous infusion of $\mathrm{E}_{2}$ resulted in a 3-fold reduction in serum $\mathrm{LH}$, irrespective of season. This $\mathrm{E}_{2}$-induced suppression of serum $\mathrm{LH}$ was reversed by concurrent episodic delivery of $\mathrm{GnRH}$. The interval between initiation of infusion and return of pretreatment concentrations of $\mathrm{LH}$ was taken as a measure of the duration of $\mathrm{E}_{2}$-induced suppression of gonadotrope responsiveness. The duration of this $E_{2}$-dependent response varied with season, with suppression of gonado-
\end{abstract}

trope responsiveness more prolonged $(P<0 \cdot 05)$ in May $(36.7 \pm 2.9 \mathrm{~h})$ than in November $(14.3 \pm 1 \cdot 1 \mathrm{~h})$. In a companion study we examined the effect of melatonin on the duration of $\mathrm{E}_{2}$-induced suppression of gonadotrope responsiveness. Wethers received blank or melatonincontaining implants in March. Sixty days after implant insertion (mid-May) wethers received $\mathrm{E}_{2}(2 \mu \mathrm{g} / 50 \mathrm{~kg}$ per h) and hourly pulses of $\mathrm{GnRH}$ (200 ng/50 kg per pulse) or saline for $72 \mathrm{~h}$. Continuous delivery of $\mathrm{E}_{2}$ alone resulted in a 3-fold decrease in serum concentrations of $\mathrm{LH}$ in both control and melatonin-treated wethers. The duration of $\mathrm{E}_{2}$-induced suppression of gonadotrope responsiveness in animals receiving $\mathrm{E}_{2}$ and $\mathrm{GnRH}$ was extended $(P<0 \cdot 05)$ in wethers with blank implants $(48 \cdot 0 \pm 0 \cdot 7 \mathrm{~h})$, relative to the duration of suppression in melatonin-treated wethers $(14.5 \pm 1 \cdot 0 \mathrm{~h})$. Taken together these data indicate that $\mathrm{E}_{2}$-induced suppression of gonadotrope responsiveness is more extended during the anoestrous season. However, this seasonal effect can be reversed by continuous administration of melatonin.

Journal of Endocrinology (1998) 158, 277-283

\section{Introduction}

Oestradiol $\left(\mathrm{E}_{2}\right)$ acts at hypothalamic and pituitary loci to reduce luteinizing hormone (LH) secretion (Clarke \& Cummins 1984, Caraty et al. 1989, Scott et al. 1997). Oestrogenic effects at hypothalamic sites lead to a reduction in the frequency of the gonadotrophin-releasing hormone $(\mathrm{GnRH})$ pulse generating system (Caraty et al. 1989, Karsch et al. 1993). Similarly, the acute response of hypophyseal targets to oestrogenic stimulation is a marked decrease in gonadotrope responsiveness, which is manifest as a reduction in the magnitude of $\mathrm{GnRH}$-induced $\mathrm{LH}$ secretion (Clarke \& Cummins 1984, Caraty et al. 1989). In ovariectomized sheep this oestrogen-dependent reduction in pituitary sensitivity is transient and gonadotrope responsiveness returns to pretreatment levels $12-24 \mathrm{~h}$ after first introduction of $\mathrm{E}_{2}$ (Clarke \& Cummins 1984, Herman \& Adams 1990). A similar biphasic shift in the magnitude of the secretory response to episodic delivery of $\mathrm{GnRH}$ is noted in $E_{2}$-treated castrated male sheep (wethers) (Sakurai \& Adams 1991, Sakurai et al. 1996).

As a photoperiod-sensitive species, sheep exhibit seasonal, or photoperiod-dependent, change in the negative feedback potency of $E_{2}$ (Legan et al. 1977). This is generally thought to reflect a seasonal shift in the activity of oestrogen-sensitive hypothalamic neurons that impinge on GnRH-containing neurons in the mediobasal hypothalamus (Gayrard et al. 1994, Havern et al. 1994, Lehman et al. 1996). The physiological response to changing photoperiod is mediated by melatonin, secretion of which is increased during the dark phase and, consequently, the duration of the nocturnal increase in the serum concentration of melatonin serves as a physiological measure of day length (Bittman et al. 1983, Bittman \& Karsch 1984). Indeed, melatonin appears to act, at least in part, at hypothalamic sites to modulate the negative feedback 
potency of $\mathrm{E}_{2}$ (Malpaux et al. 1993). Although seasonal shift in the feedback potency of oestrogenic stimuli at hypothalamic sites is well documented, recent work indicates that gonadotrope responsiveness may also vary with season or photoperiod (Xu et al. 1992, Tilbrook et al. 1993).

In the studies reported here we used wethers treated with $\mathrm{E}_{2}$ and episodic $\mathrm{GnRH}$ to test the hypothesis that the duration of oestrogen-dependent suppression of gonadotrope responsiveness varies with season. We further hypothesized that continuous treatment with melatonin would reverse this season-dependent shift in the negative feedback potency of $E_{2}$ at hypophyseal sites.

\section{Materials and Methods}

\section{Animals}

Spring- or fall-born Suffolk lambs were castrated within 2 weeks of birth. The wethers were housed in an open-sided barn under natural lighting and were afforded free access to water and alfalfa pellets supplemented with cereal grains and vitamin and mineral premix. They were 6-8 months of age (weight $60-65 \mathrm{~kg}$ ) at the time of experimentation. All experimental procedures involving the use of animals were conducted in accordance with National Institutes of Health (NIH) Guidelines and were reviewed and approved by the Animal Use and Care Committee for the University of California.

\section{Cannulation}

Before experimentation, two polyethylene cannulae (Intramedic PE 190, Clay Adams, Parsippany, NJ, USA) were inserted into the left jugular vein to serve as hormone delivery cannulae $\left(\mathrm{E}_{2}\right.$ or $\left.\mathrm{GnRH}\right)$. A third cannula (Intramedic PE 190), inserted into the contralateral vein, was used for blood collection. All cannulae were passed through a protective plastic tubing sheath to the exterior of the animal holding area. Animals were freely mobile at the end of a $1 \mathrm{~m}$ lead.

\section{Hormone delivery}

Cannulae for the delivery of $\mathrm{E}_{2}, \mathrm{GnRH}$ or the appropriate vehicle were connected to syringes placed in Harvard infusion pumps (Model 2265, Harvard Bioscience, South Natick, MA, USA). Oestradiol (Sigma Chemical Co., St Louis, MO, USA; $2 \mu \mathrm{g} / \mathrm{ml})$ in $10 \%$ ethanol-saline $\left(\mathrm{E}_{2}\right.$ delivery vehicle; $\mathrm{EV})$, or $\mathrm{EV}$ alone, was delivered as a continuous infusion.

An episodic pattern of delivery of $\mathrm{GnRH}$ (Peninsula Laboratories, Belmont, CA, USA; $200 \mathrm{ng} / 50 \mathrm{~kg}$ per h pulse) in saline, or saline alone, was effected using an infusion pump connected to an automatic timer

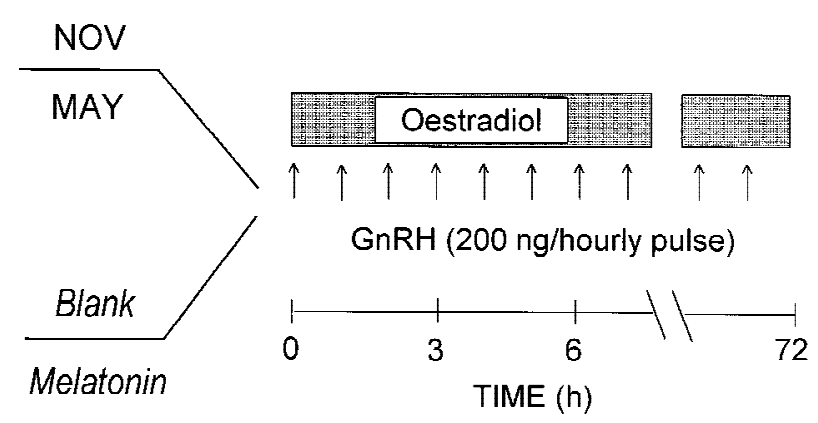

Figure 1 Experimental protocol. The effect of season and melatonin on the duration of $E_{2}$-dependent suppression of gonadotrope responsiveness was assessed in wethers receiving continuous $E_{2}(2 \mu \mathrm{g} / 50 \mathrm{~kg}$ per h$)$ and circhoral $\mathrm{GnRH}$ ( $200 \mathrm{ng} / 50 \mathrm{~kg}$ per $\mathrm{h}$ pulse) for $72 \mathrm{~h}$. The duration of the oestrogenic response was assessed during the breeding (November) and anoestrous (May) seasons. In addition, gonadotrope responsiveness was assessed in May in wethers receiving control (Blank) or melatonin-containing (Melatonin) implants 60 days earlier.

(Chrontrol, Lindburg Enterprises, San Diego, CA, USA) that was programmed to deliver a $5 \mathrm{~min}$ pulse $(1 \mathrm{ml}$ volume) once each hour. During episodic administration of $\mathrm{GnRH}$, blood samples were collected immediately before GnRH delivery.

Melatonin-containing implants were prepared using a modification of the procedure used by Diskin \& Niswender (1989) to prepare progesterone implants. Briefly, $5 \mathrm{~g}$ crystalline melatonin (Sigma Chemical Co.) were combined with $20 \mathrm{ml}$ Silastic Medical Adhesive (Type A; Dow Corning, Midland, MI, USA). The melatonin-adhesive mixture was allowed to harden after injection into a tubular mold ( $6.4 \mathrm{~mm}$ internal diameter). The melatonin-containing silastic was removed from the mold $72 \mathrm{~h}$ after injection and cut into $5 \mathrm{~cm}$ lengths. Each implant was estimated to contain $500 \mathrm{mg}$ melatonin. The implants were washed overnight in sterile saline before use. Melatonin-free, or blank, implants were prepared by deleting melatonin from the protocol described above. Serum concentrations of melatonin during exposure to sunlight (sample collection during the early afternoon) were $22 \cdot 8 \pm 3 \cdot 3$ and $119 \cdot 6 \pm 11 \cdot 1 \mathrm{pg} / \mathrm{ml}$ in sheep carrying blank and melatonin-containing implants respectively.

\section{Experiment 1}

The effect of season on the duration of the $\mathrm{E}_{2}$-dependent suppression of gonadotrope responsiveness was assessed during the breeding (November) and anoestrous (May) seasons using spring-born $(n=18)$ or fall-born $(n=18)$ wethers respectively (Fig. 1). Fall-born wethers were assigned at random to one of three treatment groups ( $n=6 /$ group) in mid-May. Continuous infusion of EV (group 1) or $E_{2}(2 \mu \mathrm{g} / 50 \mathrm{~kg}$ per h; groups 2 and 3) was 
initiated at time 0 and continued for $72 \mathrm{~h}$. Episodic administration of saline (groups 1 and 2) or GnRH (200 ng/50 kg per h pulse; group 3) was also initiated at time 0 and continued throughout the infusion period. Blood samples were collected at $2 \mathrm{~h}$ intervals during the first $24 \mathrm{~h}$ of infusion and at $4 \mathrm{~h}$ intervals thereafter. Serum was harvested and stored frozen at $-20{ }^{\circ} \mathrm{C}$ for later endocrine analysis. This experimental protocol was repeated in November using spring-born wethers.

\section{Experiment 2}

The effect of melatonin-containing implants on the duration of the $\mathrm{E}_{2}$-induced suppression of gonadotrope responsiveness in wethers was assessed during the anoestrous season (May; Fig. 1). Briefly, 28 wethers were assigned at random to one of four treatment groups. Blank (groups 1 and $2 ; n=6 /$ group) or melatonin-containing (groups 3 and $4 ; n=8$ /group) implants were inserted s.c. in mid-March. Oestrogen-dependent change in gonadotrope responsiveness was assessed in mid-May, 60 days after implant insertion. Animals in all groups received $E_{2}$ $(2 \mu \mathrm{g} / 50 \mathrm{~kg}$ per $\mathrm{h})$ as a continuous infusion for $72 \mathrm{~h}$. Animals in groups 1 and 3 received hourly pulses of saline during the infusion period, while animals in groups 2 and 4 received episodic GnRH (200 ng/50 kg per h pulse) throughout the $72 \mathrm{~h}$ period of infusion. Blood samples were collected, processed and stored as described above.

\section{Endocrine analysis}

Serum concentrations of $\mathrm{LH}, \mathrm{E}_{2}$ and melatonin were determined using previously validated procedures (Adams et al. 1975, English et al. 1986, Sakurai et al. 1992). The LH reference standard (NIAMDD-oLH-25) was a gift of the National Hormone and Pituitary Program of the National Institute of Arthritis, Metabolism, and Digestive Diseases (NIAMDD; Baltimore, MD, USA). In all cases intra- and interassay coefficients of variation were less than $10 \%$.

\section{Statistical analysis}

The significance of treatments was assessed by ANOVA or, where appropriate, ANOVA for repeated measures (Gill 1978). Differences between treatment means were tested for significance using Duncan's multiple range test. Data are presented in the text and figures as means \pm s.E.M.

\section{Results}

Serum concentrations of $\mathrm{E}_{2}$ were increased to $11 \cdot 5 \pm 0 \cdot 6$ and $11 \cdot 2 \pm 0 \cdot 2 \mathrm{pg} / \mathrm{ml}$ within $2 \mathrm{~h}$ of initiation of $\mathrm{E}_{2}$ infusion in May and November respectively, and the serum concentration of $\mathrm{E}_{2}$ remained at that level for the duration
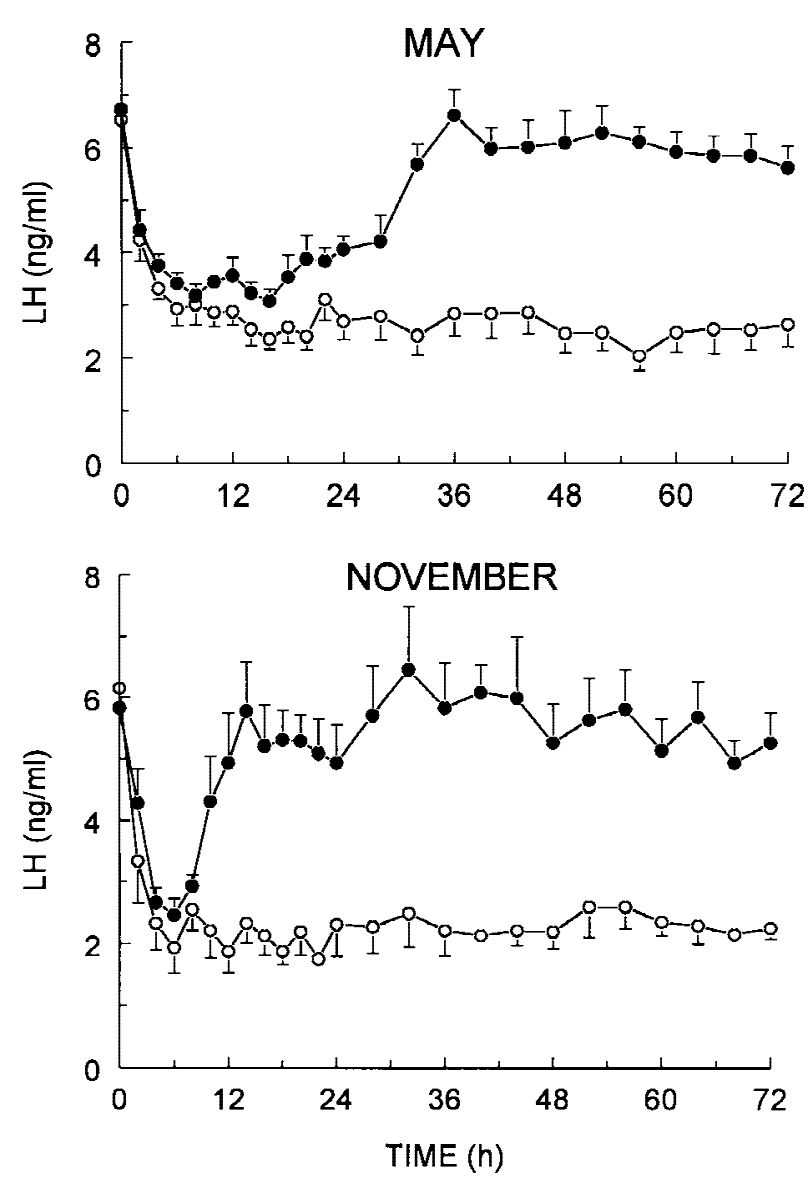

Figure 2 Serum concentrations of LH during the breeding (November) and anoestrous (May) seasons in wethers ( $n=6 /$ group) receiving continuous oestradiol $\left(\mathrm{E}_{2} ; 2 \mu \mathrm{g} / 50 \mathrm{~kg}\right.$ per h) and circhoral pulses of saline $(O)$ or $\mathrm{GnRH}(200 \mathrm{ng} / 50 \mathrm{~kg}$ per $\mathrm{h}$ pulse; ) for $72 \mathrm{~h}$.

of $\mathrm{E}_{2}$ delivery. Similarly, in experiment 2 serum concentrations of $E_{2}$ were increased to $10 \cdot 2 \pm 0 \cdot 3 \mathrm{pg} / \mathrm{ml} 2 \mathrm{~h}$ after initiation of $\mathrm{E}_{2}$ infusion and remained at this level for the duration of the infusion period. In contrast, serum concentrations of $\mathrm{E}_{2}$ were not detected $(<0.6 \mathrm{pg} / \mathrm{ml})$ in wethers receiving vehicle alone.

\section{Experiment 1}

Mean serum concentration of LH did not vary with season $(6.4 \pm 1.3$ and $5.7 \pm 0.6 \mathrm{ng} / \mathrm{ml}$ in May and November respectively) in wethers prior to treatment (Fig. 2). Similarly, serum concentrations of LH did not differ $(P>0 \cdot 05)$ from the pretreatment levels in control wethers receiving EV and hourly pulses of saline for $72 \mathrm{~h}$ in May $(5 \cdot 9 \pm 0 \cdot 4 \mathrm{ng} / \mathrm{ml})$ and November $(5 \cdot 4 \pm 0 \cdot 4 \mathrm{ng} / \mathrm{ml})$.

Continuous infusion of $\mathrm{E}_{2}$ resulted in a rapid and marked suppression of $\mathrm{LH}$ in both the breeding and anoestrous seasons (Fig. 2). In both seasons serum 
concentrations of LH were significantly $(P<0.05)$ decreased $2 \mathrm{~h}$ after initiation of $\mathrm{E}_{2}$ delivery $(4 \cdot 2 \pm 0.4$ and $3.3 \pm 0.7 \mathrm{ng} / \mathrm{ml}$ in May and November respectively) and nadir concentrations of $\mathrm{LH}$ were evident after $6 \mathrm{~h}$ of $\mathrm{E}_{2}$ administration $(2.9 \pm 0.3$ and $1.9 \pm 0.4 \mathrm{ng} / \mathrm{ml}$ in May and November respectively). In the absence of supplemental GnRH, serum concentrations of LH were maintained at nadir levels for the remainder of the $\mathrm{E}_{2}$ delivery period.

The decrease in serum LH induced by $\mathrm{E}_{2}$ infusion was evident even in wethers receiving concurrent circhoral pulses of exogenous GnRH. However, episodic delivery of $\mathrm{GnRH}$ eventually returned the serum concentration of $\mathrm{LH}$ to the pretreatment level. The duration of the $\mathrm{E}_{2^{-}}$ dependent decrease in gonadotrope responsiveness varied with season, with the interval from initiation of infusion to re-establishment of pretreatment concentrations of $\mathrm{LH}$ more extended $(P<0.05)$ in May $(36.7 \pm 2.9 \mathrm{~h})$ than November $(14 \cdot 3 \pm 1 \cdot 1 \mathrm{~h})$.

\section{Experiment 2}

Mean serum concentration of LH in May did not vary in wethers with blank $(7 \cdot 8 \pm 0.6 \mathrm{ng} / \mathrm{ml})$ or melatonincontaining $(7 \cdot 8 \pm 0 \cdot 8 \mathrm{ng} / \mathrm{ml})$ implants (Fig. 3). Initiation of $E_{2}$ infusion resulted in a rapid and marked suppression of $\mathrm{LH}$ and nadir concentrations of $\mathrm{LH}$ (evident after $6 \mathrm{~h}$ of $\mathrm{E}_{2}$ administration) did not differ in blank- or melatonintreated wethers $(2 \cdot 8 \pm 0.2$ and $3 \cdot 0 \pm 0.3 \mathrm{ng} / \mathrm{ml}$ respectively). In the absence of supplemental GnRH, serum concentrations of $\mathrm{LH}$ were maintained at nadir levels for the remainder of the $\mathrm{E}_{2}$ delivery period.

The $\mathrm{E}_{2}$-dependent decrease in serum LH was also evident in wethers receiving $\mathrm{E}_{2}$ and concurrent hourly pulses of $\mathrm{GnRH}$ and the magnitude of the oestrogendependent decrease in serum concentrations of LH did not vary $(P<0 \cdot 05)$ with melatonin treatment. After the initial decrease, serum concentrations of $\mathrm{LH}$ were returned to pretreatment concentrations in wethers receiving $E_{2}$ and episodic GnRH in combination. However, the duration of the $\mathrm{E}_{2}$-dependent decrease in gonadotrope responsiveness was significantly affected by melatonin treatment. The interval from initiation of infusion to re-establishment of pretreatment concentrations of $\mathrm{LH}$ was markedly reduced $(P<0.05)$ in melatonin-treated wethers $(14.5 \pm 1 \cdot 0 \mathrm{~h})$, relative to the duration of suppression noted in wethers with blank implants $(48 \cdot 0 \pm 0 \cdot 7 \mathrm{~h})$.

\section{Discussion}

The seasonal shift in the negative feedback potency of $E_{2}$ in seasonally breeding species, such as sheep, is well documented (Legan et al. 1977). Most studies suggest that the $\mathrm{E}_{2}$-dependent decrease in LH secretion evident during the non-breeding season reflects oestrogenic action at hypothalamic loci to reduce the frequency of episodic
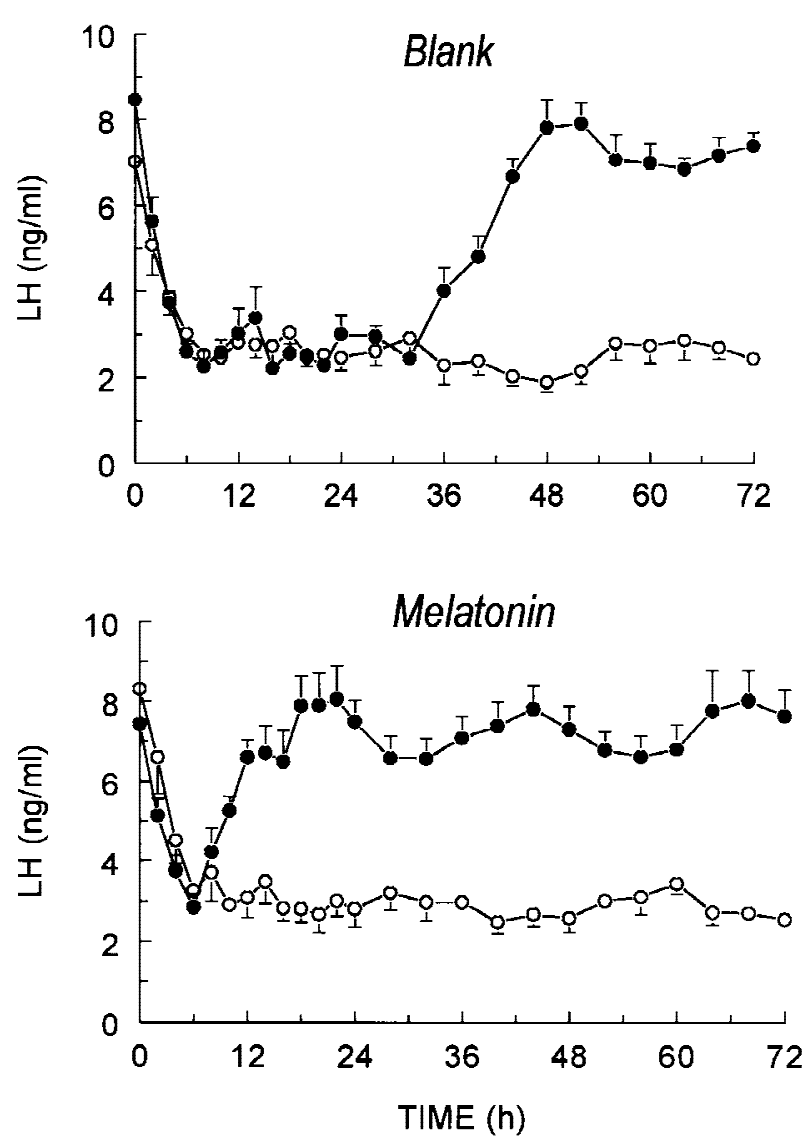

Figure 3 Serum concentrations of LH during the anoestrous (May) season in wethers treated with control (Blank; $n=6 /$ group) or melatonin-containing (Melatonin; $n=8 /$ group) implants and receiving continuous oestradiol $\left(E_{2} ; 2 \mu \mathrm{g} / 50 \mathrm{~kg}\right.$ per $\left.\mathrm{h}\right)$ and circhoral pulses of saline $(\bigcirc)$ or $\mathrm{GnRH}(200 \mathrm{ng} / 50 \mathrm{~kg}$ per h pulse; (๑) for $72 \mathrm{~h}$.

GnRH secretion (Karsch et al. 1993, Viguie et al. 1995). Indeed, pulsatile delivery of low amplitude pulses of GnRH reactivates follicular development and leads to the ovulatory surge of the gonadotrophins in sheep during the period of seasonal anoestrus (McLeod et al. 1982).

However, action at hypothalamic sites may not account, in full, for the suppressive effects of $\mathrm{E}_{2}$ on $\mathrm{LH}$ secretion. In this regard it is important to note that the onset and intensity of $\mathrm{E}_{2}$-dependent inhibition of $\mathrm{LH}$ secretion is enhanced when the oestrogenic stimulus is applied systemically, rather than directly to hypothalamic sites (Gallegos-Sanchez et al. 1996, 1997). In addition, several reports indicate that gonadal steroids act directly at hypophyseal loci to alter gonadotrope sensitivity. The direct effect of $\mathrm{E}_{2}$ on gonadotrope responsiveness is clearly evident in wethers receiving $\mathrm{E}_{2}$ and hourly pulses of $\mathrm{GnRH}$. In this treatment paradigm serum concentrations of $\mathrm{LH}$ are markedly decreased $6 \mathrm{~h}$ after first introduction of $\mathrm{E}_{2}$. However, during the breeding season pretreatment 
concentrations of $\mathrm{LH}$ are restored 12 to $24 \mathrm{~h}$ after beginning $E_{2}$ infusion in wethers receiving concurrent episodic GnRH stimulation (Sakurai \& Adams 1991, Sakurai et al. 1996). A similar biphasic pattern of LH secretion is noted in $E_{2}$-treated ovariectomized sheep made deficient in endogenous $\mathrm{GnRH}$ by hypothalamic-pituitary disconnection (Clarke \& Cummins 1984, Clarke et al. 1988) or passive immunization (Caraty et al. 1984, Herman \& Adams 1990) and receiving hourly pulses of $\mathrm{GnRH}$ or a $\mathrm{GnRH}$ agonist. Biphasic effects of $\mathrm{E}_{2}$ on gonadotrope responsiveness are also evident in vitro (Frawley \& Neill 1984, Ortmann et al. 1988). Collectively, these observations indicate that the negative feedback effects of $E_{2}$ reflect oestrogenic actions directed, at least in part, at hypophyseal loci.

In the studies presented here we used wethers receiving $\mathrm{E}_{2}$ and $\mathrm{GnRH}$ to examine the effect of season and melatonin on the duration and intensity of $\mathrm{E}_{2}$-dependent suppression of gonadotrope responsiveness. These results indicate that physiological concentrations of $E_{2}$ act acutely at hypophyseal loci to suppress gonadotrope responsiveness and $\mathrm{GnRH}$-induced $\mathrm{LH}$ secretion. Interestingly, the duration of this oestrogen-dependent response varies with season. Indeed, the pituitary-specific suppression of LH is approximately three times longer during the anoestrous season. A similar seasonal shift in gonadotrope responsiveness is evident in wethers receiving exogenous testosterone. In this model, GnRH-induced $\mathrm{LH}$ (Xu et al. 1992) and follicle-stimulating hormone (Tilbrook et al. 1993) secretion varies with season, with significantly reduced gonadotrope responsiveness during the non-breeding season.

Oestrogen is postulated to act at hypothalamic sites in a season- or photoperiod-specific manner to alter the activity of regulatory neurons that impinge on the GnRHcontaining neuronal system (Gayrard et al. 1994, Havern et al. 1994, Lehman et al. 1996, Skinner \& Herbison 1997). In contrast, the mechanism of $E_{2}$-induced decrease in pituitary responsiveness has not been determined. However, oestrogen stimulation is associated with a rapid and marked increase in pituitary concentrations of GnRH receptor (Clarke et al. 1988, Sakurai \& Adams 1991). Thus it seems likely that the reduction in gonadotrope responsiveness noted during acute oestrogenic stimulation is not related to receptor concentration but, rather, may be mediated by a decoupling of the GnRH receptor from critical second messenger systems.

The seasonal control of reproductive function in sheep is mediated by photoperiod and the duration of elevated melatonin secretion associated with the nocturnal phase (Legan et al. 1977, Bittman et al. 1983, Bittman \& Karsch 1984). The physiological response characteristic of short day length is evident even during periods of extended day length when exogenous melatonin is provided 6-8 h before the actual onset of darkness (Kennaway et al. 1982, English et al. 1986, Poulton et al. 1987). Insertion of constant release implants containing melatonin has a similar effect (English et al. 1986, Poulton et al. 1987), leading to the suggestion that continuous release implants induce the physiological response characteristic of short day length (English et al. 1986, O'Callaghan et al. 1991). Our results are consistent with this postulate since short day length or constant melatonin during periods of long day length induced the same response, a reduction in the duration of the negative feedback action of $E_{2}$ at hypophyseal loci.

In contrast to the acute oestrogenic response, GnRHinduced LH secretion is restored during more prolonged $\mathrm{E}_{2}$ stimulation. The mechanism underlying this recovery of response capacity has not been resolved. However, $\mathrm{E}_{2}$-dependent augmentation of tissue concentrations of GnRH receptor may play an important role in this process. Indeed, physiological concentrations of $\mathrm{E}_{2}$ increase tissue concentrations of $\mathrm{GnRH}$ receptor in pituitary tissue of sheep, with the maximal augmentation evident after 12 to $24 \mathrm{~h}$ of oestrogen stimulation (Clarke et al. 1988, Sakurai \& Adams 1991). Although basal concentrations of GnRH receptor do not vary with season or melatonin status (Sakurai et al. 1995, T E Adams \& H Sakurai, unpublished observations) we postulate that season and melatonin status may affect the temporal pattern of $E_{2}$-dependent increase in $\mathrm{GnRH}$ receptor, with this oestrogenic response delayed during the anestrous season.

Although the specific site of action of melatonin was not resolved in these studies, melatonin may act at both hypothalamic and hypophyseal loci to influence the negative feedback potency of $E_{2}$. The importance of action at hypothalamic sites is suggested by the observation that direct delivery of melatonin to the mediobasal hypothalamus reduces the negative feedback potency of $E_{2}$ in sheep maintained under a long day photoperiod (Malpaux et al. 1993). However, melatonin may also exert effects directly at hypophyseal sites. Indeed, hypophyseal tissue, particularly the pars tuberalis, is richly invested with melatonin receptors (Bittman \& Weaver 1990, Helliwell \& Williams 1994, Reppert et al. 1994) and is sensitive to direct stimulation by melatonin (Hazlerigg et al. 1993). Direct action of melatonin at hypophyseal sites is also suggested by the recent observation that photoperiod-dependent cycles of prolactin secretion persist after physical disconnection of the hypothalamus and pituitary in male sheep (Lincoln et al. 1996).

Collectively the data presented here indicate that $\mathrm{E}_{2}$ acts at hypothalamic and hypophyseal loci to inhibit LH secretion. The oestrogenic effect at hypophyseal sites is manifest as a transient decrease in the magnitude of GnRH-induced LH secretion. Interestingly, the duration of this $\mathrm{E}_{2}$-induced suppression of gonadotrope responsiveness fluctuates with the season, with oestrogen-dependent suppression at pituitary sites particularly extended during the non-breeding season. Constant-release melatonin implants reverse the oestrogen-dependent suppression 
of responsiveness characteristic of long day length photoperiods. The rapid onset of the negative feedback response at pituitary loci, in combination with the seasonal shift in the duration of the oestrogenic response, suggests that oestrogenic action at both hypophyseal and hypothalamic sites may act in concert to induce the profound suppression of $\mathrm{LH}$ secretion characteristic of the anoestrous period.

\section{Acknowledgements}

This work was supported by USDA Grant 93-372029111 and the California Agricultural Experiment Station.

\section{References}

Adams TE, Kinder JE, Chakraborty PK, Estergreen VL \& Reeves JJ 1975 Ewe luteal function influenced by pulsatile administration of synthetic LHRH/FSHRH. Endocrinology 97 1460-1467.

Bittman EL \& Karsch FJ 1984 Nightly duration of pineal melatonin secretion determines the reproductive response to inhibitory day length in the ewe. Biology of Reproduction 30 585-593.

Bittman EL \& Weaver DR 1990 The distribution of melatonin binding sites in neuroendocrine tissues of the ewe. Biology of Reproduction 43 986-993.

Bittman EL, Dempsey RJ \& Karsch FJ 1983 Pineal melatonin secretion drives the reproductive response to daylength in the ewe. Endocrinology 113 2276-2283.

Caraty A, Martin GB \& Montgomery G 1984 A new method for studying pituitary responsiveness in vivo using pulses of LH-RH analogue in ewes passively immunized against native LH-RH. Reproduction, Nutrition and Development 24 439-448.

Caraty A, Locatelli A \& Martin GB 1989 Biphasic response in the secretion of gonadotrophin-releasing hormone in ovariectomized ewes injected with oestradiol. Journal of Endocrinology 123 375-382.

Clarke IJ \& Cummins JT 1984 Direct pituitary effects of estrogen and progesterone on gonadotropin secretion in the ovariectomized ewe. Neuroendocrinology $39267-274$

Clarke IJ, Cummins JT, Crowder ME \& Nett TM 1988 Pituitary receptors for gonadotropin-releasing hormone in relation to changes in pituitary and plasma gonadotropins in ovariectomized hypothalamo/pituitary-disconnected ewes. II. A marked rise in receptor number during the acute feedback effects of estradiol. Biology of Reproduction 39 349-354.

Diskin MG \& Niswender GD 1989 Effect of progesterone supplementation on pregnancy and embryo survival in ewes. Journal of Animal Science 67 1559-1563.

English J, Poulton AL, Arendt J \& Symons AM 1986 A comparison of the efficiency of melatonin treatments in advancing oestrus in ewes. Journal of Reproduction and Fertility 77 321-327.

Frawley LS \& Neill JD 1984 Biphasic effects of estrogen on gonadotropin-releasing hormone-induced luteinizing hormone release in monolayer cultures of rat and monkey pituitary cells. Endocrinology 114 659-663.

Gallegos-Sanchez J, Picard S, Delaleu B, Malpaux B \& Thiery JC 1996 Initiation of the oestradiol-induced inhibition of pulsatile LH secretion in ewes under long-days: comparison of peripheral versus central treatment and neurochemical correlates. Journal of Endocrinology 151 19-28.

Gallegos-Sanchez J, Delaleu B, Caraty A, Malpaux B \& Thiery JC 1997 Estradiol acts locally within the retrochiasmatic area to inhibit pulsatile luteinizing-hormone release in the female sheep during anestrus. Biology of Reproduction 56 1544-1549.

Gayrard V, Malpaux B, Tillet Y \& Thiery JC 1994 Estradiol increases tyrosine hydroxylase activity of the A15 nucleus dopaminergic neurons during long days in the ewe. Biology of Reproduction $\mathbf{5 0}$ $1168-1177$

Gill JL 1978 Design and Analysis of Experiments in the Animal and Medical Sciences. Ames, IA: Iowa State University Press.

Havern RL, Whisnant CS \& Goodman RL 1994 Dopaminergic structures in the ovine hypothalamus mediating estradiol negative feedback in anestrous ewes. Endocrinology 134 1905-1914.

Hazlerigg DG, Gonzalez-Brito A, Lawson W, Hastings MH \& Morgan PJ 1993 Prolonged exposure to melatonin leads to time-dependent sensitization of adenylate cyclase and downregulates melatonin receptors in pars tuberalis cells from ovine pituitary. Endocrinology 132 285-292.

Helliwell RJA \& Williams LM 1994 The development of melatoninbinding sites in the ovine fetus. Journal of Endocrinology 142 475-484.

Herman ME \& Adams TE 1990 Gonadotropin secretion in ovariectomized ewes: Effect of passive immunization against gonadotropin-releasing hormone $(\mathrm{GnRH})$ and infusion of a $\mathrm{GnRH}$ agonist and estradiol. Biology of Reproduction 42 273-280.

Kennaway DJ, Gilmore TA \& Seamark RF 1982 Effect of melatonin feeding on serum prolactin and gonadotropin levels and the onset of seasonal estrous cyclicity in sheep. Endocrinology 110 1766-1772.

Karsch FJ, Dahl GE, Evans NP, Manning JM, Mayfield KP, Moenter SM \& Foster DM 1993 Seasonal changes in gonadotropin-releasing hormone secretion in the ewe. Alteration in response to the negative feedback action of estradiol. Biology of Reproduction 49 1377-1383.

Legan SJ, Karsch FJ \& Foster DL 1977 The endocrine control of seasonal reproductive function in the ewe: A marked change in response to the negative feedback action of estradiol on luteinizing hormone secretion. Endocrinology 101 818-824.

Lehman MN, Durham DM, Jansen HT, Adrian B \& Goodman RL 1996 Dopaminergic A14/A15 neurons are activated during estradiol negative feedback in anestrous, but not breeding season, ewes. Endocrinology 137 4443-4450.

Lincoln GA, Clarke IJ \& Sweeney T 1996 'Hamster-like' cycles in testicular size in the absence of gonadotrophin secretion in HPD rams exposed to long-term changes in photoperiod and treatment with melatonin. Journal of Neuroendocrinology 8 855-866.

McLeod BJ, Haresign W \& Lamming GE 1982 Response of seasonally anoestrous ewes to small-dose multiple injections of $\mathrm{GnRH}$ with and without progesterone pretreatment. Journal of Reproduction and Fertility 65 223-230.

Malpaux B, Daveau A, Maurice F, Gayrard V \& Thiery JC 1993 Short-day effects of melatonin on luteinizing hormone secretion in the ewe: Evidence for central sites of action in the mediobasal hypothalamus. Biology of Reproduction 48 752-760.

O'Callaghan D, Karsch FJ, Boland MP \& Roche JF 1991 What photoperiodic signal is provided by a continuous-release melatonin implant? Biology of Reproduction 45 927-933.

Ortmann O, Emons G, Knuppen R \& Catt KJ 1988 Inhibitory actions of keoxifene on luteinizing hormone secretion in pituitary gonadotrophs. Endocrinology 123 962-968.

Poulton AL, English J, Symons AM \& Arendt J 1987 Changes in plasma concentrations of $\mathrm{LH}, \mathrm{FSH}$ and prolactin in ewes receiving melatonin and short-photoperiod treatments to induce early onset of breeding activity. Journal of Endocrinology 112 103-111.

Reppert SM, Weaver DR \& Ebisawa T 1994 Cloning and characterization of a mammalian melatonin receptor that mediates reproductive and circadian responses. Neuron 13 1177-1185.

Sakurai H \& Adams TE 1991 Gonadotrope responsiveness in orchidectomized sheep: I. Effect of continuous infusion of estradiol. Biology of Reproduction 45 804-810. 
Sakurai H, Adams BM \& Adams TE 1992 Pattern of gonadotropinreleasing hormone $(\mathrm{GnRH})$-like stimuli sufficient to induce follicular growth and ovulation in ewes passively immunized against GnRH. Biology of Reproduction 47 177-184.

Sakurai H, Adams BM \& Adams TE 1995 Gonadotrope responsiveness in orchidectomized sheep: IV. Effect of estradiol infusion during the breeding and anestrous seasons. Biology of Reproduction 52 382-389.

Sakurai H, Adams BM \& Adams TE 1996 Gonadotrope responsiveness in orchidectomized sheep: Effect of duration of a simulated follicular phase. Journal of Reproduction and Fertility 108 211-217.

Scott CJ, Kuehl DE, Ferreira SA \& Jackson GL 1997 Hypothalamic sites of action for testosterone, dihydrotestosterone, and estrogen in the regulation of luteinizing hormone secretion in male sheep. Endocrinology 138 3686-3694.

Skinner DC \& Herbison AE 1997 Effects of photoperiod on estrogen receptor, tyrosine hydroxylase, neuropeptide $\mathrm{Y}$ and $\beta$-endorphin immunoreactivity in the ewe hypothalamus. Endocrinology 138 $2585-2595$
Tilbrook AJ, de Kretser DM \& Clarke IJ 1993 Human recombinant inhibin A and testosterone act directly at the pituitary to suppress plasma concentrations of FSH in castrated rams. Journal of Endocrinology 138 181-189.

Viguie C, Caraty A, Locatelli A \& Malpaux B 1995 Regulation of luteinizing hormone-releasing hormone $(\mathrm{LHRH})$ secretion by melatonin in the ewe. I. Simultaneous delayed increase in LHRH and luteinizing hormone pulsatile secretion. Biology of Reproduction 52 1114-1120.

Xu ZZ, McDonald MF, McCutcheon SN \& Blair HT 1992 Effects of season and testosterone treatment on gonadotrophin secretion and pituitary responsiveness to gonadotrophin-releasing hormone in castrated Romney and Poll Dorset rams. Journal of Reproduction and Fertility 95 183-190.

Received 3 October 1997

Revised manuscript received 5 February 1998 Accepted 24 February 1998 
